\title{
EDITORIAL
}

\section{LA MECÁNICA DE LA SAUDADE}

\author{
Gian Luigi De Rosa* \\ Università degli Studi Roma Tre \\ Giorgio de Marchis** \\ Università degli Studi Roma Tre
}

DOI: http://dx.doi.org/10.14718/CulturaLatinoam.2020.32.2.1

De repente volvi a mis años de infancia, cuando el lejano país llamado Portugal se confundia en mi imaginación con la dulce y fragante fruta de naranja — era el país de los "portogalli" (como dice D'Annunzio)—,

$y$ cuando me cantaron

la entonces misteriosa canción

"Vengan le grate / acque gelate / venga il pistacchio / col suo potacchio / e il portogallo / tra arancio e giallo / l'amandolata e la lattata / etc., etc.". Yo no dudé: tenía que descubrir ese país lejano, tenía que aprender sus misterios a partir de su lengua y su historia.

GiUlia LANCIANI

\footnotetext{
* Ph.D. en Culture e Istituzioni dei paesi di lingue iberiche in età moderna e contemporanea. Profesor de Lingua e Traduzione - Lingue Portoghese e Brasiliana en la Università degli Studi Roma Tre. ORCID: 0000-0001-7938-5203. Contacto: gianluigi.derosa@uniroma3.it

* * Ph.D. en Iberistica de la Universidad de Bologna. Profesor titular de Literatura portuguesa y brasileira en el Departamento de Lengua, Literaturas y Culturas Extranjeras de la Universidad Roma Tre. ORCID: 0000-002-4668-3041. Contacto: giorgio.demarchis@uniroma3.it
}

Referencia: De Rosa, G. L. - de Marchis, G. (2020). Editorial. La mecánica de la saudade. Cultura Latinoamericana, 32 (2), pp. 17-20. DOI: http://dx.doi.org/10.14718/ CulturaLatinoam.2020.32.2.1 
Escribir de una pérdida, de la pérdida de un maestro para un investigador universitario es difícil. Es difícil describir la saudade que esa ausencia deja en el alma de quien sigue estudiando, siguiendo la senda trazada por quien se ha ido. Saudade, en portugués, porque, a pesar de la dificultad de traducirla, se trata de una palabra que semánticamente dice más de lo que podríamos decir y describir. Cuando, en el otoño de 2018, Giulia Lanciani nos dejó, aunque todos sabíamos que su estado de salud era delicado, nadie quiso creer en esa noticia tan triste. Ella, que fue profesora titular de literatura portuguesa y brasileña en la Universidad Roma Tre, y que se graduó en la Facultad de Letras y Filosofía de la Universidad "La Sapienza" de Roma, donde ganó el concurso como asistente para después enseñar en las Universidades de Venecia $(\mathrm{Ca}$ ' Foscari) y de Roma (Facultad de Magisterio de "La Sapienza"; Facultad de Letras y Filosofía, Roma Tre), en los últimos meses tuvo que alejarse de la Universidad, institución a la que había dedicado 50 años de estudio y entusiasmo.

Sin embargo, y a pesar de todo, existe una genealogía del saber que se despliega a través de modelos de estudio y de conocimiento, ejemplos de rigor intelectual, pero también de gustos e idiosincrasia cultural, que los maestros transmiten a sus alumnos y que persisten de generación en generación. La búsqueda desinteresada de lo auténtico, que Giulia Lanciani consideraba «una especie de libido delectandi», y el respeto ineludible al texto literario constituyen, desde este punto de vista, el legado que esta estudiosa ha dejado a los muchos que han tenido la suerte de formarse siguiendo los pasos de su magisterio. Como confirmación de un vínculo intelectual que perdura mucho más allá de los límites de la existencia individual, en los últimos dos años se han producido numerosos homenajes y testimonios de afecto y gratitud que los lusitanistas de todo el mundo han hecho a esta rigurosa filóloga, brillante traductora y destacada estudiosa de la lengua portuguesa y de las literaturas portuguesa y brasileña.

Por eso, agradecemos a la revista Cultura Latinoamericana, y aún más a su director, el profesor Antonio Scocozza, que al magisterio y a la formación de alumnos ha dedicado toda su vida, que hayan querido recordar, dos años después de su muerte, a una colega y amiga a través de las páginas de este editorial. Solo tres de sus discípulos participan de este número de Cultura Latinoamericana, pero el grupo podría haber sido mucho más consistente, porque los discípulos de Giulia Lanciani son muchos y, ciertamente, no se limitan a los aquí presentes. Van mucho más allá y en nombre de esos vínculos intelectuales que 
unen generaciones, incluso distantes, y se perpetúan para reafirmar la deuda intelectual, pero también la gratitud y el afecto que tienen por su enseñanza.

La contribución de Giulia Lanciani al estudio de la literatura portuguesa y brasileña abarca un período de tiempo que va desde la poesía lírica medieval gallega y portuguesa hasta el mundo contemporáneo. El libro La meccanica dell'errore (cuyo título utilizamos, modificándolo, para este editorial), publicado en 2010, reúne varios ensayos suyos sobre la literatura medieval en la península ibérica centro-occidental, en los que la autora aborda cuestiones metodológicas, reconstruye perfiles de trovadores e investiga las relaciones culturales y los entornos que los estimularon.

En cualquier caso, son muchos los ámbitos en los que la contribución de Giulia Lanciani ha permitido iluminar aspectos de la poesía lírica de la Edad Media hispánica según el modelo provenzal. A tal propósito, el monumental Dicionário da Literatura Medieval Galega e Portuguesa, publicado en 1993 y editado en colaboración con Giuseppe Tavani, sigue siendo en este sentido una obra de referencia imprescindible. Su contribución científica al lusitanismo no se limita al estudio de la literatura de los orígenes, sino que también es posible encontrar constantes metodológicas en sus obras dedicadas a los autores modernos y contemporáneos, en la cuales la necesidad de no descuidar la reconstrucción del cuadro histórico, de fijar siempre las obras en un lugar y un momento precisos, por ejemplo, es una constante, y vuelve a aparecer también en sus numerosos estudios dedicados a la literatura de los siglos XVI y XVII.

La formación filológica de esta lusitanista-mor también prorrumpe cada vez que tuvo la oportunidad de dedicarse, con obstinado rigor, a la obra de los escritores portugueses y brasileños del siglo XX. Desde este punto de vista, la referencia al carácter dinámico del carácter textual presente en diversas contribuciones suyas solo nos puede conducir a su trabajo en el campo de la genética literaria. Las ediciones y estudios dedicados a las etapas preparatorias de las obras de Manuel Bandeira, Carlos de Oliveira y Fernando Pessoa siguen siendo ejemplares en este sentido.

Otro aspecto fundamental de los múltiples intereses de esta embajadora de poesía, como la llamó el poeta Manuel Alegre, es la traducción. De hecho, gran parte de lo mejor que han producido las literaturas portuguesa y brasileña durante el siglo XX habla en italiano con la voz de esta estudiosa, a quien el Ministerio de Patrimonio y Actividades Culturales concedió, en 2003, el Premio Nacional de 
Traducción. Ente los autores que tradujo podemos citar aquí las traducciones de los portugueses Manuel Alegre, José Saramago, Fernando Namora, Pedro Tamen, Ruy Belo, Sophia de Mello Breyner Andresen, Teresa Rita Lopes, Vasco Graça Moura, Eugénio de Andrade, Gastão Cruz, Nuno Júdice y José Luís Peixoto, pero también las de los brasileños Jorge Amado y Carlos Drummond de Andrade y, sobre todo, la traducción de los 21 cuentos de Primeiras estórias de João Guimarães Rosa, de la que Giulia estaba muy orgullosa.

Si el lusitanismo internacional ha recibido tanto de esta estudiosa italiana, que nunca perdió de vista la necesidad de la formación de sus alumnos, la deuda que la lusitanística italiana tiene con Giulia Lanciani es incalculable, y los numerosos volúmenes para homenajearla y recordarla publicados en los últimos dos años dan fe de una profunda y sincera gratitud.

Pero ¿a qué se debe esta historia de navegaciones lingüísticas y descubrimientos literarios? Para recordar a Giulia Lanciani, nada mejor que sus propias palabras, quizás porque es mas fácil recordar a nuestra maestra hablando de cómo empezó su lusofilia, de cómo empezó una pasión que se volvió un vínculo que va más allá de la misma vida y que, en el recuerdo, nos dejó huérfanos.

«Mi pasión por Portugal y la cultura lusitana tiene un origen que podría definir como casual. Cuando me inscribí en la Facultad de Letras y Filosofía de "La Sapienza", a la edad de dieciocho años, conocía bien la lengua y la cultura francesas, suficientemente la inglesa, y tenía un conocimiento del alemán y de su literatura. El deseo de ampliar mis horizontes, y al mismo tiempo mi curiosidad por entrar en contacto con culturas a las que asistí muy poco o nada, me llevó a explorar la lista de idiomas cuya enseñanza ofrecía la Facultad. Cuando llegué a portugués, de repente volví a mis años de infancia, cuando el lejano país llamado Portugal se confundía en mi imaginación con la dulce y fragante fruta de naranja —era el país de los "portogalli" (como dice D’Annunzio)—, y cuando me cantaron la entonces misteriosa canción "Vengan le grate / acque gelate / venga il pistacchio / col suo potacchio / e il portogallo / tra arancio e giallo / l'amandolata e la lattata / etc., etc.", yo no dudé: tenía que descubrir ese país lejano, tenía que aprender sus misterios a partir de su lengua y su historia».

In memoriam

Giulia Lanciani (1935-2018) 